\title{
Defender of the Natural Rights Faith
}

\author{
To Secure These Rights: The Declaration of Independence and Constitutional \\ Interpretation. By Scott D. Gerber." New York: New York University Press, \\ 1995. Pp. xv, 315. $\$ 45.00$.
}

The question of whether constitutional interpretation ought to emphasize the intended meanings of the Framers, as discerned from the text itself and relevant historical sources, remains a highly charged political issue. Conservatives generally espouse originalist methodology as a basis for rejecting the liberal court decisions and "judicial activism" of the $1960 \mathrm{~s},{ }^{1}$ while liberals reject the originalists' methodological claims and defend the propriety of judicial discretion, which has tended to produce outcomes to which they are sympathetic. ${ }^{2}$ With To Secure These Rights, Scott D. Gerber enters the debate over the Framers' intent by rejecting the presumption that a "jurisprudence of original intention" need be a "jurisprudence of the right;" Gerber attempts, instead, to develop a "liberal originalis[t]" theory of constitutional interpretation, one which, though faithful to original intent, yields liberal results (pp. 4-7).

Gerber's call for a liberal originalism is intriguing, but the particular originalist vision he offers is less than compelling. Gerber argues that the Constitution's drafters intended their creation to achieve one central purpose: the protection of the natural rights delineated in the Declaration of Independence. The Declaration, according to Gerber, expressed the Lockean natural rights theory that animated the Revolution. The Constitution, in turn,

* Visiting Assistant Professor of Government, College of William and Mary.

1. See generally ROBERT H. BORK, THE TEMPTING OF AMERICA: THE POLITICAL SEDUCTION OF THE LAW (1990) (defending originalist position on constitutional interpretation); Edwin Meese III, Toward a Jurisprudence of Original Intent, 11 HARV. J.L. \& PUB. POL'Y 5 (1988) (same); William H. Rehnquist, The Notion of a Living Constitution, in VIEWS FROM THE BENCH: THE JUDICIARY AND CONSTITUTIONAL PoLITICS 127 (Mark W. Cannon \& David M. O'Brien eds., 1985) (rejecting notion that Constitution should be conceived of as evolving document); Antonin Scalia, Originalism: The Lesser Evil, 57 U. CIN. L. REV. 849 (1989) (advocating originalist methodology as best approach to constitutional interpretation).

2. See generally William J. Brennan, Jr., The Constitution of the United States: Contemporary Ratification, 27 S. TEX. L. REV. 433 (1986) (advocating approach to constitutional interpretation that centers on what text means in our time); H. Jefferson Powell, The Original Understanding of Original Intent, 98 HARV. L. REV. 885 (1985) (arguing Framers intended Constitution to evolve through its interpretation in accordance with modern conditions and values); Laurence H. Tribe, Bicentennial Blues: To Praise the Constitution or To Bury It? 37 AM. U. L. REV. 1 (1987) (rejecting originalist emphasis on Framers' intent). 
established a national governmental structure for the protection of those rights. The Supreme Court, as the ultimate protector of these rights, properly enjoys the role of final arbiter of constitutional interpretation. Unfortunately, Gerber's argument is crippled by the inadequacy of his historical scholarship and by his sometimes unrealistic view of the American political system today.

\section{II}

Gerber begins with a discussion of the intellectual climate and political philosophy of the Revolutionary Era. Looking both to primary sources and to the arguments advanced by an earlier generation of historians who identified the character of the American Revolution as firmly rooted in the Lockean theory of natural rights, ${ }^{3}$ Gerber rejects the prevailing trend in Revolutionary historiography, "republican revisionism." Instead, he asserts that "on the issue of the basic purpose of government-the issue of preeminent concern to constitutional interpretation . . . the intellectual leaders were Lockean liberals, not classical republicans" (p. 33); the Declaration of Independence, in Gerber's view, expressed "the essential political premise of the American regime ... that government exists to secure natural rights, not to cultivate virtue" (p. 40).

Gerber then contends that "the primary goal of [the Constitution was] to provide the institutional means to secure the natural-rights philosophical ends of the Declaration" (p. 59). Gerber argues that the preamble to the Constitution, the framing and ratification debates, and the Federalist Papers all demonstrate that "the Founders remained as dedicated to natural-rights principles during the period of the framing and ratification of the Constitution as they had been during the heyday of the American Revolution" (p. 90).

Based on this reading of the Framers' intent, Gerber argues in the second part of the book that the proper role of the Supreme Court is to be the guardian of the natural rights of the people and, thus, the final arbiter of constitutional interpretation. Gerber argues that, as the Framers became increasingly suspicious of the legislative branch's ability to protect citizens'

3. In thus depicting the Revolution as Lockean in character, Gerber seems strongly influenced by the work of a previous generation of Revolutionary historians, such as Carl Becker and Louis Hartz, see generally CARL L. BECKER, THE DECLARATION OF INDEPENDENCE 27-30, 71-79 (6th prtg. 1956) (describing Locke's influence on Founders); LOUIS HARTZ, THE LIBERAL TRADITION IN AMERICA 50-64 (1955) (same), and natural rights interpreters of the Constitution, including Harry Jaffa and Walter Murphy, all of whose works he cites frequently.

4. Republican revisionism, or the "republican synthesis," de-emphasizes the influence of Locke and natural rights theory on the intellectual leaders of the Revolution and points to the influence of classical republicanism, the importance of the concept of virtue, and the contributions of British Whig, Scottish, and Continental political thought to the Revolutionaries' political outlook. See, e.g., BERNARD BAILYN, THE IDEOLOGICAL ORIGINS OF THE AMERICAN REvolution at xi-xii, 34-54 (1967); J.G.A. POCOCK, THE MACHIAVELLIAN MOMENT: FLORENTINE POLITICAL THOUGHT AND THE ATLANTIC REPUBLICAN TRADITION 462-67, 506-52 (1975); GORDON S. WOOD, THE CREATION OF THE AMERICAN REPUBLIC, 1776-1787 at vii-ix, 6-9, 48-70 (1969). See generally Robert E. Shalhope, Republicanism and Early American Historiography, 43 WM. \& MARY Q. 29 (1986) (reviewing briefly central ideas of republican synthesis.) 
natural rights, especially in light of the failures of the national and state governments under the Articles of Confederation, they moved from the traditional English model of legislative supremacy to one recognizing the validity of judicial review (pp. 99-100).

Gerber also appeals to the structure of the Constitution to support his contention that the Framers intended the Court to act as the final interpreter of that document. Gerber asserts that "the Founders' acceptance of judicial finality is evident in the structure of government they embodied in the Constitution, specifically in the complementary mechanisms of separation of powers and checks and balances," since "[w]ithout the power of definitive judicial review" the Court would have no effective check on the other two branches (p. 128). Gerber also notes that, without one branch as final interpreter, "constitutional gridlock" would occur and that the meritocratic judiciary has particular institutional competence as a textual interpreter (p. 133).

Having set forth his conception of the appropriate role of the judiciary in constitutional interpretation, Gerber moves on to address the restraints available to "prevent the Court's role as the ultimate interpreter of the Constitution from devolving into the unacceptable state of government by judiciary" (p. 134). According to Gerber, the checks placed upon the Court by the Constitution-the Article V amendment process (pp. 139-44), impeachment (pp. 144-49), ${ }^{5}$ judicial self-restraint (pp. 150-54), and the judicial appointment process (pp. 154-60) -if exercised to the extent intended by the Framers, "can help ensure that the Court interprets the Constitution in accordance with the natural-rights philosophy of the Declaration of Independence, rather than in light of the moral and political convictions of particular justices" (p. 161).

Gerber concludes the volume by applying a natural rights theory of constitutional interpretation to a handful of the issues recently confronted by the Court, including discrimination and abortion (pp. 164-95). Gerber acknowledges that the views of the Framers need not control the outcome of modern cases, since their views on issues such as racial and sexual equality were not always consistent with the natural rights theory embodied in the Declaration and the Constitution (p. 165). But he still attempts to demonstrate "that the political philosophy of the Declaration of Independence is sufficiently determinate to be a practical guide to judgment in individual cases that come before the Court" (p. 162).

5. In proposing partial reliance on the impeachment power to prevent judges from deciding issues based on their own political and moral preferences, Gerber makes an interesting argument that such attempts to amend the Constitution outside the Article $\mathrm{V}$ process qualify as "high crimes and misdemeanors" and thus constitute grounds for impeachment, since "nothing could more 'subvert the Constitution' than intentionally disregarding the philosophical principles on which [it] is erected" (p. 149). Gerber goes on to insist, "[a]s unsettling as the impeachment process may sometimes seem, the Constitution requires that it be sometimes used" and that "only if the impeachment power is taken more seriously [can] the natural-rights principles upon which this nation is based ... be reaffirmed" (p. 149). 


\section{III}

In laying the foundation for his theory of constitutional interpretation based on natural rights, Gerber oversimplifies the extensive and influential scholarship of the republican revisionist movement by characterizing it as asserting that "the motivating force behind the American Revolution was not the protection of natural rights, but the cultivation of virtue" (p. 25). Gerber's rejection of the republican synthesis relies primarily on an examination of the text of the Declaration of Independence and other writings by leaders of the Revolutionary period, including Thomas Jefferson, Samuel Adams, and James Madison. On the basis of their heavy rhetorical dependence on the language of Locke's Second Treatise, ${ }^{6}$ Gerber declares triumphantly that the Declaration is rooted exclusively in Lockean natural rights theory.

This attempt to redeem Revolutionary liberalism talks past the republican revisionist movement, rather than rebutting it. Even in their strongest statements, advocates of the republican synthesis have never denied that Revolutionary thinkers were influenced by Locke and dependent upon Lockean rhetoric; rather they attempted to draw attention to other significant influences, which had been ignored by earlier generations of historians, and to demonstrate Revolutionary leaders' willingness to borrow both rhetoric and ideas from any and every source available to them. ${ }^{7}$ Without a definitive rebuttal of the republican synthesis and redemption of the earlier emphasis on Locke alone, at least with regard to the purpose of government, Gerber's demand for constitutional interpretation based solely on natural rights theory cannot succeed.

On the basis of his own analysis of primary sources, Gerber also dismisses existing scholarship on the circumstances surrounding the framing and ratification of the Constitution ${ }^{8}$ and oversimplifies the forces at work in the Constitutional era. He shifts much of the burden of proving the Framers' intent in drafting the Constitution back to his questionable interpretation of the Revolutionary period. He concedes that there was "little philosophizing about the ultimate ends of government during the confederation period" and the

6. JOHN LOCKE, The Second Treatise of Government, in Two TREATISES OF GOVERNMENT 265 (Peter Laslett ed., student ed. 1988) (3d ed. 1698).

7. See, e.g., WOOD, supra note 4, at 6-9 (describing varied sources upon which Revolutionary leaders drew, including not only Locke but also thinkers in traditions of classical antiquity, Christian theology, English empiricism, and European rationalism).

8. Gerber illustrates his contention that the historiography is flawed in its "focus mainly on contexts at the expense of texts" by citing a few noted works on the Constitutional Convention (p. 58): JACK P. GREENE, PERIPHERIES AND CENTER: CONSTITUTIONAL DEVELOPMENT IN THE EXTENDED POLITIES OF THE BRITISH EMPIRE AND THE UNITED STATES, 1607-1788 (1986) (addressing problems created by governing large territories under Articles of Confederation); FORREST MCDONALD, NOVUS ORDO SECLORUM: THE INTELLECTUAL ORIGINS OF THE CONSTITUTION (1985) (focusing on Framers' desire to promote specific economic and political theories); RICHARD B. MORRIS, THE FORGING OF THE UNION, 1781-1789 (1987) (emphasizing inability of Articles government to address various economic and foreign policy issues). 
Convention itself," but he takes this silence as evidence that "the matter was so well settled by the Declaration of Independence: the fundamental purpose of government is to secure the natural rights of the people" (p. 63).

According to Gerber, the context in which the relevant historical documents were created-the focus of much current historiography-is not important for determining the "fundamental purpose of the state" (p. 59). These purposes must be gleaned from the texts themselves. Thus, the social, political, and economic circumstances surrounding the drafting of the Constitution become secondary for Gerber, leaving him free to sift the sources for phrases and paragraphs that support his thesis regarding the preeminence of natural rights concerns. Gerber scours the writings of leaders such as Madison, Adams, Jefferson, and Hamilton for remarks that seem to support a sustained commitment to Lockean natural rights theory throughout the Constitutional period. ${ }^{10}$ Gerber's interpretations of The Federalist and the Bill of Rights likewise emphasize rhetoric that, while consistent with and clearly influenced by Locke, is not necessarily dispositive of the Framers' view of the basic purposes of government.

Even if the reader accepts Gerber's arguments regarding the Declaration and the Constitution, it is difficult to imagine that the Court could or would function as Gerber proposes. Regardless of whether the Framers believed that the Court could live up to such lofty expectations, Gerber's vision of the judiciary as an essentially apolitical defender of natural rights and his proposed checks on the branch are often unrealistic. In emphasizing amendment and impeachment as protections against judicial abuse and error, Gerber dismisses claims that these processes are infrequently used because they are clumsy and ineffective, ${ }^{11}$ and he overlooks the inherent difficulty in building the extensive political consensus required to employ them. In defending the Article $\mathrm{V}$ amendment process, Gerber highlights the several amendments that overturned Supreme Court precedent as evidence that the amendment process can be used to address judicial abuse or error. ${ }^{12}$ But this analysis is also flawed: Gerber

9. See Jack N. Rakove, The Beginnings of National Politics: An InTERPREtive History of THE CONTINENTAL CONGRESS 183-91 (1979) (noting little discussion of political philosophy during Confederation period and Constitutional Convention of 1787).

10. Gerber dismisses claims that leaders such as John Adams and Alexander Hamilton had abandoned natural rights theory in the post-Revolutionary era; Gerber insists, for example, that even though "[i]n order to press for his preferred strong national government, Hamilton did sometimes employ what can only be described as a strained interpretation of Lockean liberalism. ... [F]or Hamilton, as for the Framers in general, Lockean liberalism remained the benchmark of political legitimacy" (pp. 84-85).

11. See WALTER F. MURPHY ET AL., AMERICAN CONSTITUTIONAL INTERPRETATION 1768-69 (1986); Stephen L. Carter, Constitutional Adjudication and the Indeterminate Text: A Preliminary Defense of an Imperfect Muddle, 94 YALE L.J. 821, 843 (1985) (declaring Article V "very nearly a dead letter").

Gerber rejects arguments that the infrequent use of the impeachment process is a positive phenomenon in American politics. See, e.g., JOHN AGRESTO, THE SUPREME COURT AND CONSTITUTIONAL DEMOCRACY 120 (1984); William H. Rehnquist, The Impeachment Clause: A Wild Card in the Constitution, 85 Nw. U. L. REV. 903, 903-04 (1991).

12. Compare Chisholm v. Georgia, 2 U.S. (2 Dall.) 419 (1793) (holding citizen of one state may sue another state in federal court) with U.S. CONST. amend. XI; Scott v. Sanford, 60 U.S. (19 How.) 393 (1857) 
fails to note that, although Supreme Court precedents created the need for each of these amendments, most of them were passed not in direct response to those precedents but in response to intervening events or changes (for the Thirteenth through Fifteenth Amendments, the Civil War and Reconstruction; for the Twenty-Sixth Amendment, the Vietnam draft).

Gerber also depends on politicians to foster a meritocratic, nonpartisan judiciary by abandoning the well-established practices of political appointment. However, instead of addressing how to motivate such conduct, he asserts that politicians have access to the necessary information and expertise, and demands they "stop playing politics with the appointment process" (p. 160). ${ }^{13}$ Gerber is similarly naive in relying on politicians to refrain from mounting partisan impeachment efforts. ${ }^{14} \mathrm{He}$ also demands that judges ignore their personal beliefs in favor of whatever natural rights theory seems to require; ${ }^{15}$ he is confident that properly selected judges are capable of exercising such self-restraint (p. 150). Unfortunately, these political arguments, like Gerber's historical claims, seem to be based more on preference than analysis.

—Wendy Ann Semel

(holding African-American slaves are not citizens) with U.S. CONST. amends. XIII, XIV, XV; Pollack v. Farmers' Loan \& Trust Co. 157 U.S. 429 (1895) (holding federal income tax unconstitutional) with U.S. CONST. amend. XVI; Oregon v. Mitchell, 400 U.S. 112 (1970) (holding congressional attempt to lower voting age in state and local elections to 18 unconstitutional) with U.S. CONST, amend. XXVI.

13. But see DAvid M. O'BRIEN, JudicIAL RouletTE 98 (1988) (describing political nature of appointment process).

14. This rejection of political impeachments comes despite Gerber's acknowledgement of President Gerald Ford's attempt to impeach Justice William Douglas in response to congressional rejection of two Republican Supreme Court nominees and the liberalism of the Warren Court (pp. 146-47).

15. In many cases, Gerber admits that these requirements may not presently be discemable. For example, while he notes that natural rights theory will not be able to resolve the question of whether or not there is a constitutional right to abortion until science can definitively determine when life begins (p. 182), Gerber offers no suggestion how the Court ought to adjudicate the issue for the present day. 